\title{
The Classical Music Culture of South India
}

\author{
MOHAN RAMANAN \\ University of Hyderabad \\ mohanramanan1949@gmail.com
}

Received: 16-07-2013

Accepted: 07-01-2014

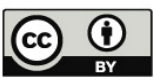

\begin{abstract}
The paper sketches briefly the cultural and political context against which one may study the classical South Indian concert called the Kutcheri. It goes on to trace the development of the modern concert and then concentrates on the devotional poetry of Tyagaraja who is the foremost composer in the tradition. The paper demonstrates the centrality of Bhakti (devotion) as an emotion and its role in creating a link between the composer, the singer, the song and the audience.
\end{abstract}

KEYWORDS: Kutcheri; Bharatanatyam; National discourse; Bhakti (devotion); Tyagaraja's songs

\section{RESUMEN La cultura musical clásica del sur de la India}

El artículo esboza brevemente el contexto cultural y político en el que se puede analizar el concierto de música clásica del sur de la India conocido como Kutcheri. Rastrea el desarrollo del concierto moderno y se centra en la poesía devota de Tyagaraja que es el más importante compositor en esta tradición. El artículo constata la importancia de Bhakti (devoción) entendida como emoción y su papel en la creación de un vínculo entre el compositor, el/la cantante, la canción y el público.

Palabras Clave: Kutcheri; Bharatanatyam; discurso nacional; Bhakti (devoción); las canciones de Tyagaraja

The South Indian music concert is called a Kutcheri, and its present form is more or less linked to the founding of the Music Academy in Chennai (then Madras) in 1927. The Academy organizes an annual conference which has become world-famous and a much looked forward to social event. Even those who are not particularly musical like to attend these concerts as they have become an important marker of social status. The music season in this institution and elsewhere in Chennai has an emphasis on South Indian cuisine and the display of various arts and crafts. It is therefore also a commercial event. Thus both the professional musician and the layperson find something in this season to look forward to.

A strict and methodical organization of the music concerts is another feature of the Music Academy event and no musician will take more time or sing less than the allotted time. Thus there is a pressure on the musician to fine-hone the concert and to time it scrupulously. 
Usually a concert is about two and a half hours, a far cry from the more expansive musical feasts of the Courts and temples in an earlier day. Karnatak music is to be distinguished from Hindustani music, the latter forming the North Indian Classical tradition. The term Karnatak also has strong connections with the state of Karnataka from where the chief Karnatak composer, Purandaradasa, came. Purandaradasa was responsible for systematizing the basic lessons from simple notes to gitams (short easily memorizable verses) and kirtanas (more elaborate compositions with at least three verses) and he provided the basis for the efflorescence in South Indian music which took place in the nineteenth century. So the concert proper is a modern variation or avatar of the larger and longer musical feats of an earlier day. It is also a modulation from the Bhajana (devotional group singing) tradition which is still alive and vigorous and which is known for its accelerating rhythms, naming of the Lord and devotion tending towards enthusiasm and frenzy. The classical Kutcheri on the other hand establishes a strict frame work of rhythm within which permutations and combinations are encouraged, the beat or tala remaining the same and constant. The Kutcheri then is a formal and stylized version of what used to exist prior to the establishment of the Music Academy and the Sabhas (organizations which promote music and musicians and organize events) and in its two or two and a half hours' duration a severe classicism is demanded from both the musicians and their audiences. There is a clear and well recognized way in which a Kutcheri may be organized (PGV Ramanan \& Mohan Ramanan, in Marathe and Mukherjee, 1986). One begins with a varnam which is an exercise to get the voice, tone and rhythm under control. Then follow kritis or kirtanas (a stylized composition) apostrophizing one or other Deity. A concert begins invariably with an invocation to Ganapati, the remover of obstacles, and then goes on to detail the qualities of other Deities like Kartikeya, the commander-in-chief of the army of the Gods, the brother of Ganapati, both of whom are children of Ambal, the Mother Goddess and Siva, the Destroyer. Then follow compositions on Vishnu, the Preserver, and His manifestations such as Rama, the hero of the Ramayana and Krishna, the great philosopher hero of the Mahabharata, and so on. After the bulk of these kritis have been rendered along with Raga Alapana (melodic variations of a limited number of notes which are distinct from other combinations of notes) and Neraval (elaboration of a phrase from the kriti to bring out not only the poetic excellence of the phrasing but also to demonstrate the musician's imaginative grasp of melody and rhythm) and Swaram (rhythmic variations of notes with all kinds of mathematical calculations getting musical expression), we have the major piece which is the RTP or Ragam, Tanam and Pallavi. The Raga chosen for exhaustive elaboration 
is the main Raga of the concert, while other Ragas chosen are detailed less comprehensively. The main Raga is sung for roughly double or triple the time taken for the elaboration of minor Ragas; the Tanam (musical rendering of the word Ananta - which means eternal in Sanskrit in rhythmic variations) is sung, and a complicated rhythmic exercise called a Pallavi is demonstrated. After this we have the Tukadas (literally fragments and short compositions), the Javalis and the Padams (both forms usually associated with dance and celebrating divine love), but also part of a music concert. Then comes the mangalam or auspicious conclusion.

A Karnatak musician has to be proficient in Raga (melody), Bhava (feeling and mature handling of devotional experience) and Tala (Rhythm) and know at least five or six languages which are the basis for kritis. Knowing what you are singing is important and enhances the value of the concert. Above all devotion is basic and the alpha, beta and gamma of Karnatak music is Bhakti or devotion. The Kritis themselves are part of the Bhakti literature of India and a composer like Tyagaraja, on whom I shall say more a little later, was a great devotee of his favourite God, Rama, the hero of the Ramayana. In the compositions we see every mood and tone of voice, every inflection of devotion and every attitude of the devotee from grief at the loss of contact with the Deity to ecstasy at union. Suffice it to say here that Karnatak music is a well developed tradition and the musical Trinity of Tyagaraja, Dikshithar and Syama Sastri are at the centre with musicians and critics enabling this to happen. It is canon formation and without for a moment questioning the undoubted artistic merit of the Trinity it is necessary to historicize things and remember that the nationalist movement which was strong at the time appropriated the arts for nation building and in identity formation. The mythification of the Trinity needs to be seen as a religious exercise calculated to promote a sense of reverence for hoary tradition and by implication Hindu India.

The trajectory has been, as Lakshmi Subramanian points out, from the Tanjore Court to the modern Sabha or the Proscenium stage (Subramanian, 2011). In the Court the musician sang under patronage and was well rewarded for his efforts. A class of performers in music and dance called the Devadasis, dismissed by the British ruling class as Nautch girls (derogatory for dancer), was also prominent in temples, but nationalist sentiment, combined with the moral posture of the British colonial masters, brought in legislation to ban Nautch and the practice of dedicating women to the Deity. The fear that Devadasis encouraged immorality and prostitution was responsible for this nationalist counter-attack (Saskia Kersenboom, 1987; Soneji, 2012). The evolution of the Karnatak Kutcheri must be seen in the context of the sanitizing zeal of the reformers. Dance which was originally the preserve of the Devadasi community and called Sadr modulated in the twentieth century into Bharatanatyam. As the 
term suggests it is the dance of Bharata (the Hindu name for India), based on the principles of the aesthetician Bharata's Natyasastra. From the overt body consciousness and emphasis on Srngara or Beauty in Sadr the emphasis was now on Bhakti or devotion and a stylized classical body language shorn of overt sensuality. It must be noted that Beauty and Devotion are in a dynamic mix in Bharatanatyam and should not be seen as binary opposites, but the emphasis was clearly on Beauty being subsumed under Devotion (Sriram, 2007; Leela and Samson, 2010). The connection between the Kutcheri and Bharatanatyam is close and the development of Sadr into Bharatanatyam and the Bhajana tradition into the Kutcheri may be seen as parallel phenomena. Both participate in national discourse. When we speak, as we will do now in this essay, about the Kutcheri, it will be necessary to remember this piece of historical sanitization and recognize the form with all its beauty as having elided the woman and the subaltern and foregrounded the Brahminical. The Brahmins are the intellectuals in Hindu society and they are at the top of the caste structure of Hindu society. When we say Brahminical we allude to their role in keeping the scriptural tradition intact and in our context anyone who preserves the essence of the artistic tradition is Brahminical. The Kutcheri was for a long time the preserve of the male and dominated by the Brahmins. But the subaltern element of women and male players of the wind instrument, the Nagaswaram, broke through caste taboos to set up a tradition of their own. This was made possible by the likes of Bangalore Nagarathnamma, who played a great role in enabling women artists to break the Brahminical male hegemony. One needs to also laud the work of eminent women artists like M.S. Subbalakshmi, M.L. Vasantakumari and D.K. Pattamal who broke through to enter a male bastion and took it by storm (T.J.S. George, 2004 and Indra Menon, 1989). Their careers enabled a large number of women to take up a career in music, and women performers now probably outnumber male ones at the Sabhas and at the annual Aradhana (observance of the anniversary of the death) of the saint Tyagaraja in Tiruvaiyar. Similarly non-Brahmin players of the Nagaswaram (a wind instrument associated with the lower-caste barber community) are now permitted to play inside the Samadhi (place of burial), which for a long time was not allowed by Brahminical orthodoxy (Sriram, 2007). The concert today bears the mark of these elisions and these inclusions. The Padams and Javalis, which were the Devadasi forte, are now sung as Tukadas at the end of a concert as light pieces after the heavy classical fare has been exhausted. During the days of the Sadr and the Devadasis they were central to the repertoire. 
I shall briefly now consider the Trinity of Karnatak music, which as noted is central to the musical tradition. True, there was an efflorescence of Karnatak music in the nineteenth century (Ramanujachari \& Raghavan: 1958). Of the Trinity comprising Tyagaraja, Dikshithar and Syama Sastri, the most popular is Tyagaraja. His compositions are usually - to quote William Wordsworth - a 'spontaneous overflow of powerful feelings' and he moves the listener both with his lyrical beauty and the intensity of his devotion. In Hindu culture one chooses a favourite manifestation of God and worships Him in a variety of ways. Tyagaraja's Ishta (favourite) Deity was Lord Rama, the iconic hero of the epic Ramayana. In Dikshithar's compositions, mostly in classical and learned Sanskrit, there is a Miltonic grandeur and the architectonics of a Dikshithar composition resemble the great temple gopurams (towers) of the South of India (Ramanan in Narasimhaiah, 1994). In his compositions we see emotion recollected in tranquility, while in Tyagaraja, as we have suggested above, there is a Wordsworthian spontaneity. When we come to Syama Sastri we see a beautiful combination of Tyagaraja's emotional appeal and Dikshithar's classicism. Sastri usually pleads with Kamakshi, his Ishta Devata (favourite Deity) who is the Mother Goddess of the South Indian pilgrimage centre Kanchi. He is the child pleading before the Mother. I have already suggested that the apotheosis of the Trinity is coterminous with the formation of the Music Academy. The alteration of $S a d r$ into Bharatnatyam is linked to developments in politics where the Nationalists and the Moderates between them were contending for supremacy and finally Gandhi came out successful as the undisputed leader of Indian nationalism. It is not an accident that M.S. Subbalakshmi was a protégé of C.R. (Rajagopalachari), the foremost disciple of Mahatma Gandhi in South India, and even sang in later years at the UN a song composed by Rajaji, as C.R. is called. It is also significant that the Tamil Isai movement promoted the compositions of the fiery patriot Subramania Bharathi and all three women singers - M.S. Subbalakshmi, D.K. Pattammal and M.L. Vasanta Kumari - sang his compositions. Musicians were, in a subtle way, drafted into the nationalist cause and it is reasonable to suggest that both the music Kutcheri and the foregrounding of the Trinity had much to do both with aesthetics and with representing the Nation.

Having put these political concerns behind us, we may now concentrate primarily on an exploration of the aesthetic qualities of Karnatak music and in particular the Bhakti tradition. Bhakti or devotion, as I have said, is central to South Indian music and Beauty gets subsumed under it. Indeed one could say that one's appreciation of the Beauty of a composition is in direct proportion to the Bhakti in it or the intensity of it. The composer is a Bhakta (devotee), the singer who sings the composition is a Bhakta, transmitting the Bhakti of 
the composer and the listener is also in a Bhakti-filled mood receiving the musical experience which will not be complete until all three - composer, singer, listener - are part of this discourse of Bhakti.

Bhakti is a psychological category and in the communicative act which a Karnatak Kutcheri is, both the singer and the listener, also called a Rasika, are going through a psychological process. The singer internalizes the compositions of, say, the Trinity and arrives at a spiritual state, then transmits this state to the Rasika (literally one who absorbs the Rasa or essence of the music) and leaves him or her in a state 'calm of mind, all passion spent.' Karnatak music is from beginning to end spiritual in its dimensions and is closely linked to religious devotion. Now Bhakti can be designated an emotion for the purposes of this paper. When India's Adi kavi, or First poet, Valmiki, composed the Ramayana it is said that he was moved by the spectacle of the killing of a Krauncha bird by a Nishada hunter and the sight of the mate in grief moved the poet to curse the hunter in a particular rhythm. This we know is the Anushtup meter and the entire poem, it is said, was the direct result of Valmiki internalizing the rhythm and giving expression to his sorrow (Soka). From Soka comes Sloka (verse). After all it is the poet Shelley who says that "our sweetest songs are those that tell of saddest thoughts." In the context of the spiritual process, is there anything more excruciating and sorrowful than separation from God? Devotees have given varied expression to this. Karnatak music is part of that spiritual quest for oneness with God and the condition of this separation from God is the warp and woof of the compositions of the greatest composers. In Karnatak music the emotion of Bhakti is central, and in what follows we will attempt an exploration of how Karnatak music not only expresses emotion from the point of view of the composer and the musician but also affects the emotional nature of the Bhakta (devotee), the listener or the recipient of the message in music. It is a three-way process. We have the composer - say a Thyagaraja or a Muthuswami Dikshithar or a Syama Sastry or an Annamaya. They have, along with many other composers, given us a repertoire of Kritis (compositions) which keeps a musician busy throughout his or her life. The musician learns the kritis by the Vedic method of Sravana Bhakti (listening with devotion) and internalizes the nuances and beauties of the Kriti, which is made up of Sahitya or a core of words which have signification, set in a Tala or rhythm (we have a minimum of 32 rhythms with permutations and combinations amongst them) and a Raga or a melody which is a strict demarcation of the notes which may be used and the nuances or Gamakas which the musicians may allow themselves. As Muthuswami Dikshithar put it in his Kalyani kriti, "Bhaja Re" music must 
have "Bhava, Raga and Tala". That is to say it must have an emotional mood, a melody in which to express that mood, and a rhythmic pattern which will give structure to the composition. Free verse is unknown to Karnatak composers and Tala is akin to metre. As Coleridge and other theorists have put it, metre is meant to control the emotion and give it significant form by aestheticizing what otherwise would be inchoate.

For a moment put yourself in the composer's place. You are affected by the beauty of the Lord, you recognize your affinity to Him, and you also know that you are separated from Him and that your purpose in life is to seek Him and to merge with Him. You compose a kriti. Here is one:

\author{
Emani Vegintune Sri Rama Rama \\ Emani Vegintu Nentani Sairintu \\ Na Muddu Devudu Nanu Basenayyaayyo \\ Palinci Lalinci Palumaru Kaugulinci Telinci \\ Nanu Para desi Seya Doceno \\ Adina Muccatana Dantarangamu Ninda \\ Nidu Ledani Yunti Nin Daka Sarivarilo \\ Edabayaka Tyagaraju Nelu Sri harini Dolli \\ Badalikarcci Naceyi Battinadi Talcucu
}

(Ramanujachari \& Raghavan, 1958: 477-78)

This is Tyagaraja's kriti in the Huseni Raga set to Adi Tala. It says: "Oh Rama! How can I live and how long am I to endure it? My beloved Lord has forsaken me. After treating me so long with endearing affection, embracing me often, and cheering me up, have you now thought of abandoning me as a stranger? The sweet words you spoke to me and the way in which you previously took me by the hand and rid me of my troubles, have so filled that heart that I have till now considered myself unequalled.” (Ramanujachari \& Raghavan, 1958: 478).

The circumstances of Saint Tyagaraja's life may be briefly enumerated . He was born in 1767 and mastered the art of music from an early age. For our purposes it is apposite to note that Tyagaraja was moving around what is now the Kaveri region in the Tanjavur district of today's Tamil Nadu state, where he internalized a mode of Bhakti which had become prominent there - the tradition begun by Narayana Tirtha, Sadasiva Brahmendra and Bodhendra. They chanted the Lord's name, and it is called Nama Siddhanta and is considered as the most potent means of realizing and remembering God. Tyagaraja also learnt from the 
reformist zeal of Purandaradasa, called the Pitamaha or Grandsire of Karnatak music. In this tradition the strain of Rama Bhakti, derived from Ramananda, Tulsi Das and Bhadrachala Ramadas, also influenced him, as did also the various Bhajana Mathas (organizations where devotional music was sung) dotted all over the Tanjavur area which popularized the NamaSankirtana and Rama Bhakti. The Hari Katha, derived from the Maratha country but now domiciled in Tanjavur, also had its impact on Tyagaraja. Being the heir to this rich tradition of Bhakti, the emotional makeup of the composer made him ready for the trials of the spirit. It is in this context that one reads the Kriti just quoted.

Tyagaraja in the piece goes through several emotional nuances. There is the admission that he has been close to his ideal Rama whom he had spoken to endearingly, thinking it would last. But it is not to be. He is a sinner and he has lost contact with the Lord. He has to struggle and endure this separation. He even scolds and points an accusing finger at Rama saying that he is uncaring, insensitive and cruel. Tyagaraja can take these liberties (he is even more candid in other kritis) and he feels the separation from Godhead keenly. His pride that he had exclusive contact with Rama is now punctured and he gives expression to what Christian mystics term the 'Dark Night of the Soul' in his closing lines. It is by all accounts a moving piece of poetry. And this is the first point I want to make. Karnatak music is not abstract and there is a strong base of Sahitya or text to make it concrete. First of all the musician rendering the composition will have to know the meaning of the song. The words are important and contribute to the emotional experience.

It is at this stage that the musician intuits the essential harmony between the Bhava or emotion which is sad, regretful and plaintive in the Kriti. The choice of the Raga Huseni in the kriti mentioned above seems appropriate because the rendition in that Raga of the Sahitya seems to harmonize. The Adi Tala also gives the necessary length and duration for the exploration of the mood and the meaning of the composition. Everything bespeaks integrity and organic unity with no distracting element of aporia to violate that integrity.

At this point it will be helpful to invoke the notion of Sahrdayata in Sanskrit aesthetic tradition The Kavi or composer expresses himself or herself in the full flow of a creative imagination at work. This is called Kavayitri Pratibha or creative imagination. The aesthetic emotion is internalized by the recipient or the listener. He or she has what is called Bhavayitri Pratibha or the responsive imagination. Now a listener who has this quality of the imagination clearly is a Sahrdaya or one who is after the heart of the singer, who in turn is after the heart of the composer. Thus a line of communication between the composer, the singer, the song 
and the Rasika is set up and all stages in this communicative process are informed by the emotion of Bhakti.

Tyagaraja's compositions express the full range of Bhakti. There is a ninefold division of Bhakti and Tyagaraja explores all nine. Devotion may be expressed according to the Narada Bhakti Sutras, a widely recognized treatise on devotion, in nine ways. These are: Sravanam (listening to the name of the Lord), Keertanam (singing His praise), Smaranam (remembering the Lord's play and attributes), Paadasevanam (service of the divine feet), Archanam (worship), Vandanam (prostration), Daasyam (servitude), Sakhyam (friendship) and finally Atmanivedanam (self-surrender). A devotee can begin anywhere but the end of all devotion is atmanivedanam or self-surrender and total absorption in the Deity. Karnatak music, and Tyagaraja's, moves through all these modes, but ultimately the singer and the listener, with the assistance of the composer, aim at self-transcendence and at obtaining a state of beatitude which subsume both beauty and devotion. Devotion and music, as the Seer Ganapathi Satchidananda says, go together.

All music has evolved out of Om, the mystic syllable which symbolizes the Absolute. To worship God through music is called Nadopasana. Nadopasana or Shabdopasana is a great meditation. It washes the mind of fears and evil thought and fills the mind with peace and tranquility. Bhojana (food) is for the development of the body, so is Bhajan (singing in praise of God) for the development of the soul. (Swamiji, nd).

Tyagaraja's music may be understood in the context of this statement by Swamiji. In his compositions, while all the moods are developed or explained, this final absorption is the unifying thread linking all.

Thyagaraja, as I have pointed out elsewhere, is a mystic musician, and as I said, explores all nine modes of devotion (Ramanan, 2012). For him total identification with Lord Rama is the end to be desired. Separation brought on the despair which Christian mystics call the Dark Night of the Soul and when he realizes God he is ecstatic and in a state of beatitude. In several songs he has failed to realize this identity between the 'I' and 'Thou', the subject and the object. In one Kriti he despairs and in anguish to cries out:

Where has he hidden himself? When will

He have the mercy to come to me? (Ramanan 2013: 54)

And in his Goulipantu Kriti 'Entapapinaiti' he says: 
Oh Rama! What a sinner have I become? What shall I do? How can I bear? Having once had darsan of Sri Hari the dispeller of all sorrows, can any one bear separation from him? Having treated me before with affection, has he now taken into his head to tease me with a deceitful mind? Was it ordered by Brahma that I should undergo suffering, abandoning my hopes? I do not find my beloved Lord. I have been regarding service to Him as my life's sustenance. My fate has come to this. The Lord whom I used to worship with ecstatic love is not with me now.

(Ramanujachari \& Raghavan 1958: 477).

Tyagaraja sees himself as bride to Rama's husbandhood. This is in the great tradition of Bridal mysticism. He gives expression to it in 'Eti Janma iti Ha' in Raga Varali by saying:

Oh Rama! what a life is this? Why did I have it at all and how long am I to bear it? Life will be useless and the heart parched up, if it is not given to one to have frequent vision of the peerless and beautiful Lord and exchange of words with him, to see to one's eyes' content your chest with shining pearl necklace and your youthful face, and to embrace, to satiation of the swelling desire, you, who can sense others' minds and delight in music. What is the life of one not blessed with your sight and whose heart is thereby parched up? (Ramanujachari \& Raghavan 1958: 484).

Elsewhere Tyagaraja says:

Oh my Lord! Why is it that you do not talk to me? Is it fair that others should laugh at me? What is the reason for your being angry with me? I have always danced to your tune. 'Palukavemi na Daivama' (Raga Puranchandrika) (Ramanujachari \& Raghavan 1958: 485) -

and finally, in yet another kriti, he says:

Oh Ramachandra! What else is there for me to aspire for when you take one by the hand and cast your benign look on me? 
When my look and your look fit in with each other properly, who can know the happiness that I then will derive?

(Ramanujachari \& Raghavan 1958: 487).

I shall conclude by quoting myself:

This brief exposition of Tyagaraja's Bhakti mysticism, I trust, demonstrates how the ineffable spiritual state of mystic oneness gets musical expression in the Kritis of Tyagaraja. If that state is undifferentiated, then Tyagaraja lived in that state for long periods. We must, however, see the varied moods, modes and stages of Bhakti, in fact as the morphology of that undifferentiated state, indeed giving local habitation and a name to what otherwise would be ineffable, and because ineffable, ungraspable. Listening to Tyagaraja's Kritis with devotion and reverence allows us lesser mortals to experience the mystical state, ever so slightly (Ramanan 2012: 55).

\section{WORKS CITED}

GeOrge, T.J.S. MS: A Life in Music. Delhi: Harper Collins, 2004.

Kersenboom, Saskia. Nityasumangali: Devadasi Tradition in South India. Delhi: Motilal Banarsides Publishers, 1987.

MenOn, IndRA. The Madras Quartet: Women in Karnatak Music. Delhi: Roli, 2008.

Ramanan, P.G.V. And Mohan Ramanan. "The Karnatak Kutcheri as Narrative", in Sudhakar Marathe, Meenakshi Mukherjee, E.D. Narasimaia (eds.), Narrative: Forms \& Transformations. Delhi: Chankya Pub., 1986: 155-65.

RAMANAN, MoHAN. "The Aesthetic Experience of a Dikthithar Kriti", in C.D. Narasimhaiah (ed.), East-West Poetics at Work. Delhi: Sahitya Akademi, 1994: 248-56.

Ramanan, Mohan. "Tyagaraja's Mystic Music", Journal of the Henry Martyn Institute, Vol. 31 (Jan.-Dec. 2012): 51-55.

Ramanujachari, C. And Raghavan, V. The Spiritual Heritage of Tyagaraja. Text in Devangari and English translation of the songs of Tyagaraja by C. Ramanujachari. An Introductory Thesis by Dr. V. Raghavan. Chennai [Madras]: Ramakrishna Mission Students' Homes, 1958.

SAmson, LedA. Rukmini Devi: A Life. Delhi: Penguin, 2010.

SoneJ, Davesh. Unfinished Gestures: Devadasis, Memory and Modernity in South India. Bangalore: Orient Blackswan, 2012. 
SRIRAM, V. The Devadasi and the Saint: The Life \& Times of Bangalore Nagarathnamma. Chennai: East West Press (Madras) Pvt. Ltd, 2007.

Subramanian, LaKshmi. From the Tanjore Court to the Music Academy: A Social History of Music in South India. Oxford: OUP, 2011.

SwamiJi, SRi Ganapati SaChChiDAnAndA. God Word vol. 1. Mysore: Sri Ganapati Sachchidananda Avadoota Datta Peetham, New Delhi. nd. 